\title{
PERHITUNGAN DAN PELAPORAN PPH PASAL 21 ATAS GAJI PEGAWAI NEGERI SIPIL GOLONGAN III PADA BADAN PERTANAHAN NASIONAL KABUPATEN BULELENG
}

\author{
Putu Krisna Govinda \\ Jurusan Akuntansi Program Diploma III, Universitas Pendidikan Ganesha, Singaraja \\ govinda.krisna@gmail.com
}

\begin{abstract}
Abstrak
Penelitian ini bertujuan untuk mengetahui Perhitungan Dan Pelaporan PPh Pasal 21 Atas Gaji Pegawai Negeri Sipil Golongan III pada Badan Pertanahan Nasional Kabupaten Buleleng. Tehnik pengumpulan data menggunakan 2 metode yakni; Metode dokumentasi, Metode Wawancara. Subjek penelitian adalah Pegawai Negeri Sipil Golongan III pada Badan Pertanahan Nasional Kabupaten Buleleng dan obyek perhitungan dan pelaporan PPh Pasal 21. Data yang digunakan adalah data kuantitatif dan kualitatif. Selanjutnya data akan dianalisis dengan menggunakan analisis deskriptif kuanlitatif dengan cara memaparkan perhitungan dan pelaporan pph pasal 21 Atas Gaji Pegawai Negeri Sipil Golongan III pada Badan Pertanahan Nasional Kabupaten Buleleng. Hasil penelitian menunjukkan proses perhitungan PPh Pasal 21 atas gaji Pegawai Negeri Sipil Golongan III Badan Pertanahan Nasional Kabupaten Buleleng tahun 2016 dilakukan oleh bendahara pengeluaran. Dimana besar pajak terutang yang dilaporkan bendahara pengeluaran totalnya sebesar Rp29.750.604 sedangkan jika dihitung bedasarkan Undang-undang No 36 Tahun 2008 totalnya sebesar Rp80.147. jadi ada selisih sebesar Rp29.590.301.
\end{abstract}

Kata Kunci : Penelitian Gaji Pegawai Negeri

\section{Abstact}

This study aims to determine the Calculation and Reporting of Income Tax Article 21 on the Salaries of Civil Servants Group III on the National Land Agency of Buleleng Regency. Techniques of data collection using 2 methods namely; Documentation method, Interview Method. Research subjects are Civil Servants Group III on the National Land Agency of Buleleng Regency and the object of calculation and reporting of Article 21 Income Tax. Data used are quantitative and qualitative data. Furthermore, the data will be analyzed by using descriptive analysis kuanlitatif by describing the calculation and reporting pph Article 21 Upper Salary of Civil Servants Group III on the National Land Agency Buleleng Regency.

The result of the research shows that the calculation process of Article 21 Income Tax on the salary of Civil Servant of Group III of the National Land Agency of Buleleng Regency in 2016 is conducted by the treasurer of expenditure. Where the amount of tax payable reported by the treasurer of total expenses amounted to Rp29.750.604 whereas if calculated describing Act No. 36 of 2008 total of Rp80.147. So there is a difference of Rp29.590.301.

Keywords:Civil Servants Salary Research

\section{Pendahuluan}

Pemahaman akan peraturan perpajakan menjadi sangat penting bagi para wajib pajak agar bisa menghitung kewajiban pajaknya dengan tepat, karena salah satu faktor yang dapat mempengaruhi menurunkan kepatuhan wajib pajak dalam membayar dan melaporkan pajaknya yaitu kurangnya pemahaman dan pengetahuan akan peraturan perpajakan. Tingkat kepatuhan wajib pajak yang paling utama adalah tingkat kepatuhannya dalam penyampaian Surat Pemberitahuan (SPT) Tahunan maupun masa secara benar dan tepat pada waktunya. Berdasarkan latarbelakang diatas dapat ditemukan beberapa rumusan masalah:

1. Bagaimanakah perhitungan pajak penghasilan pasal 21 (PPh) yang 
dikenakan atas gaji pegawai negeri sipil golongan III pada kantor Badan Pertanahan Nasional Kabupaten Buleleng apakah sesuai dengan UU No. 36 Tahun 2008 ?

2. Bagaimanakah pelaporan $\mathrm{PPh}$ pasal 21 yang telah dilakukan atas gaji pegawai negeri sipil golongan III pada kantor Badan Pertanahan Nasional Kabupaten Buleleng ?

Adapun tujuan dari penelitian ini adalah sebagai berikut.

1. Untuk mengetahui bagaimanakah perhitungan pajak penghasilan pasal 21 (PPh pasal 21) yang dikenakan terhadap gaji pegawai negeri sipil golongan III pada kantor Badan Pertanahan Nasional Kabupaten Buleleng sudah sesuai dengan UU N0. 36 Tahun 2008 PPh.

2. Untuk mengetahui bagaimana proses pelaporan yang dilakukan oleh pihak Badan Pertanahan Nasional Kabupaten Buleleng terhadap pajak terutang PPh pasal 21 yang dikenakan kepada pegawai.

Hasil dari penelitian ini diharapkan dapat menambah referensi di perpustakaan. Hasil ini juga diharapkan bermanfaat bagi mahasiswa lain atau bagi peneliti lainnya yang ingin meneliti tentang perhitungan dan pelaporan PPh pasal 21 untuk Peagawai Negeri Sipil Golongan III khususnya di Badan Pertanahan Nasional Kabupaten Buleleng.

\section{Metode Penelitian}

Rancangan penelitian (Sugiyono, 2003:302) adalah pedoman yang berisi langkahlangkah yang diikuti oleh peneliti untuk melakukan penelitiannya. Rancangan penelitian harus dibuat secara sistematis dan logis sehingga dapat dijadikan pedoman yang betulbetul mudah diikuti.

Penelitian ini dilakukan untuk memperoleh informasi mengenai perhitungan dan pelaporan PPh pasal 21 atas gaji Pegawai Negeri Golongan III pada Kantor Badan Pertanahan Nasional Kabupaten Buleleng pada bulan April 2017. Berdasarkan judul penelitian, maka penelitian ini menggunakan rancangan penelitian deskriptif, karena penelitian ini menjelaskan atau memaparkan apa yang terjadi sesungguhnya dilapangan. Penelitian ini didahului dengan mengunjungi Kantor Badan Pertanahan Nasional Kabupaten Buleleng, kemudian melakukan observasi atas permasalahan yang utamanya terkait dengan perhitungan dan pelaporan pajak PPh pasal 21. Dalam mengumpulkan data peneliti menggunakan data primer yaitu data yang dikumpulkan secara langsung melalui wawancara seperti cara pelaporan pajak. Selain data primer penulis menggunakan data sekunder yaitu data yang diperoleh dari dokumen dan catatan- catatan yang berkaitan dengan penelitian yang sudah ada seperti data gaji Pegawai Negeri Golongan III pada Kantor Badan Pertanahan Nasional Kabupaten Buleleng. Teknik dalam pengumpulan data yang akan digunakan dalam memperoleh data - data tersebut adalah metode wawancara, observasi dan metode dokumentasi. Data yang sudah terkumpul akan dianalisis dengan menggunakan anilisis deskriptif kuantitatif dan deskriptif kualitatif. Dari teknik analisis yang digunakan diharapkan bisa mengetahui dan menyimpulkan bagaimana perhitungan dan pelaporan terhadap PPh pasal 21 yang dikenakan terhadap gaji Pegawai Negeri Golongan III pada Kantor Badan Pertanahan Nasional Kabupaten Buleleng. Penelitian ini dilakukan pada pada Badan Pertanahan Nasional (BPN) Kabupaten Buleleng yang beralamat di jalan Jalan Dewi Sartika Selatan No 24 Singaraja-Bali.

Adapun subjek dari penelitian ini adalah Pegawai Negeri Golongan III pada Kantor Badan Pertanahan Nasional Kabupaten Buleleng. Sedangkan objek penelitian ini adalah perhitungan dan pelaporan terhadap PPh pasal 21

\section{Jenis dan Sumber Data}

1. Berdasarkan Sifat Data

a) Kuantitatif yaitu data yang diperoleh dalam bentuk angka-angka yang dapat dihitung, seperti jumlah penghasilan bruto dan tarif pajak yang dikenakan terhadap gaji 
Pegawai Negeri Golongan III pada Kantor Badan Pertanahan Nasional Kabupaten Buleleng.

b) Kualitatif yaitu data yang diperoleh berupa uraian-uraian atau dokumen, seperti sejarah perusahaan, struktur organisasi, daftar nama pegawai dan data-data lainnya yang mendukung penelitian.

2. Bedasarkan Sumber Data

a) Data Primer yaitu data yang dikumpulkan secara langsung melalui wawancara atau observasi, cara pelaporan pajak yang dilakukan oleh Bendahara Badan Pertanahan Nasional Kabupaten Buleleng

b) Data Sekunder yaitu data yang diperoleh dalam bentuk laporan yang sudah jadi dan diolah oleh pihak lain atau data yang lebih dahulu dikumpulkan dan dilaporkan oleh pihak luar dari penulis sendiri, contohnya adalah daftar perhitungan gaji.

\section{Metode Pengumpulan Data}

Adapun metode pengumpulan data yang dilakukan untuk penelitian adalah:

a) Wawancara yaitu pengumpulan data melalui tanya jawab yang dilakukan kepada bandahara pemotong pajak untuk penghasilan Pegawai Negeri Golongan III pada Kantor Badan Pertanahan Nasional Kabupaten Buleleng

b) Dokumentasi yaitu pengumpulan data dengan cara studi dokumen atau mencatat dokumen yang akan dijadikan data dalam penyusunan penelitian seperti meminta data slip gaji Pegawai Negeri Golongan III pada Kantor Badan Pertanahan Nasional Kabupaten Buleleng.

c) Observasi dengan mengamati proses perhitungan dan pemotongan pajak PPh pasal 21 terhadap Pegawai Negeri Golongan III pada Kantor Badan Pertanahan Nasional Kabupaten Buleleng.

\section{Teknik Analisis Data}

Setelah data-data yang diperlukan berhasil dikumpulkan, maka langkah selanjutnya adalah penganalisisan sebagai upaya dalam pemecahan atas permasalahan yang telah diuraikan sebelumnya. Penelitian ini dilakukan dengan tehnik analisis Deskriptif Kuantitatif. Untuk mendiskripsi bagaimana perhitungan dan pelaporan pajak PPh pasal 21apakah sudah sesuai dengan undang-undang No. 36 Tahun 2008, peneliti juga menggunakan teknik analisis deskriptif kualitatif untuk mengetahui bagaimana perhitungan dan pemotongan pajak PPh pasal 21 terhadap Pegawai Negeri Golongan III pada Kantor Badan Pertanahan Nasional Kabupaten Buleleng.

\section{Hasil dan Pembahasan}

Hasil Perhitungan : Badan Pertanahan Nasional memiliki kelebihan pembayaran PPh Pasal 21 tahun 2016 sebesarRp 29.750.603 -Rp.80.147= Rp. 29.590.301. Kelebihan pembayaran tersebut disebabkan karena bendaharawan pemotong dalam menghitung PPh pasal 21 tidak mengikuti peraturan perundang-undangan yang berlaku, melainkan hanya berpedoman pada tunjangan pajak penghasilan yang diberikan oleh Negara terhadap Pegawai Negeri Sipil Golongan III Badan Pertanahan Nasional Kabupaten Buleleng. Jadi asumsi bendahara pengeluaran adalah PPh Pasal 21 terutang sama besarnya dengan tunjangan pajak penghasilan yang diterima pegawai.

Pelaporan: Untuk pelaporan SPT tahunan Pegawai Negeri Sipil Golongan III Badan Pertanahan Nasional Kabupaten Buleleng dilakukan secara online, dimana pelaporan pajak secara online ini merupakan program dari pemerintah yang tujuannya untuk memudahkan wajib pajak khususnya Pegawai Negeri Sipil melaporkan pajak PPh Pasal 21 terutang setiap tahunnya. Jadi wajib pajak tidak perlu melakukan pelaporan secara manual ke kantor pelayanan pajak, namun dengan mengisi data-data yang diminta dalam formulir yang tersedia dalam aplikasi E-SPT. Setelah formulir diisi dengan baik dan benar maka wajib pajak melaporkanya dengan mengirim melalui e-mail. 
VOL.7, NO. 1, APRIL 2018

p-ISSN : 2337-537X

\section{Pembahasan}

Perhitungan : Untuk perhitungan PPh Pasal 21, yang terlebih dahulu harus benar perhitunggannya adalah perhitungan gaji bruto pegawai. Setelah itu gaji bruto dikurangi biaya jabatan dan iuran pensiun untuk mendapatkan penghasilan netto pegawai.sedangkan untuk menghitung PPh Pasal 21 terutang perhitungannya adalah (Penghasilan Netto PTKP) x Tarif Undang-Undang No 36 Tahun 2008. kesalahan bendahara pengeluaran Badan Pertanahan Nasional Kabupaten Buleleng Terletak pada perhitungan gaji bruto dan perhitungan PPh Pasal 21. Karena bendahara hanya menambahkan tunjangan istri, tunjangan anak, tunjangan struktural, dan tunjangan beras ke dalam gaji pokok untuk menghitung gaji brutonya. Sedangkan kalau dilihat dari rekapan gaji yang tersedia dalam Lampiran 1, Pegawai Negeri Sipil Golongan III juga menerima Tunjangan Pajak Penghasilan yang seharusnya ditambahkah dengan gaji pokok untuk mendapatkan nominal gaji bruto. Sedangkan untuk perhitungan PPh Pasal 21 bendahara tidak mengikuti peraturan undangundang karena bendahara mencamtumkan PPh Pasal 21 berdasarkan tunjangan pajak penghasilan yang diterima pegawai. Jadi nominal tunjangan pajak penghasilan merupakan nominal PPh Pasal 21 Terutang menurut bendahara Badan Pertanahan Nasional Kabupaten Buleleng. Sedangkan menurut undang-undang cara menghitung PPh Pasal 21 adalah (Penghasilan Netto - PTKP) x Tarif Undang-Undang No 36 Tahun 2008. perhitungan yang sesuai dengan teori dan undang-undang yang berlaku. Jadi hasilnya adalah hanya 1 pegawai yang memiliki pajak PPh Pasal 21 Terutang, sedangkan perhitungan bendahara Badan Pertanahan Nasional Kabupaten Buleleng seluruh Pegawai Dikenakan PPh Pasal 21. Ini berarti bahwa ada perbedaan antara perhitungan yang dilakukan oleh bendahara Badan Pertanahan Nasional dengan perhitungan yang sesuai dengan UU No 36 Tahun 2008. Perbedaannya terletak pada proses perhitungan gaji bruto yang seharusnya ditambahkan tumjangan pajak penghasilan. Selain itu pada perhitungan pajak PPh Pasal 21 yang dihitung bendahara pengeluaran terdapat kesalahan karna nominal pajak terutang disamakan dengan nominal tunjangan pajak penghasilan, sedangkan menurut UndangUndang adalah (Penghasilan Netto - PTKP) x Tarif Undang-Undang No 36 Tahun 2008.

Pelaporan : Pada Badan Pertanahan Nasional pelaporan PPh Pasal 21 dilakukan secara online, bendahara pengeluaran mengatakan proses dan langkah-langkah pelaporannya mengikuti cara yang terdapat pada website resmi Direktorat Jendral Pajak. 


\section{Daftar Pustaka}

Andriani, 1999, Perpajakan Indonesia. Jakarta.

Diana, Anastasia,danLilisSetiawati, 2004. Perpajakan Indonesia. Yogyakarta, Penerbit Andi

Ikatan Akuntansi Indonesia. 2002. Standar Akuntansi Keuangan per 1 April 20012, Jakarta, Penerbit Salemba Empat

Mardiasmo. 2011. Perpajakan, Edisi Revisi 2011. Yogyakarta, Penerbit Andi.

Mardiasmo. 2011 : 2. Syarat Pemungutan Pajak, Edisi Revisi 2011. Yogyakarta, Penerbit Andi.

Munawir, 2000. Pokok-pokok perpajakan. Yogyakarta, Penerbit Liberty.

Munawir. 2011:21. Ketentuan Umum dan Cara Perpajakan, Yogyakarta ,Andi

$\mathrm{PPh}$ pasal 21 terhadap pegawai negeri sipil (PNS), Tersedia pada (http://www.pphpasal21padaPNS.) Diakses tanggal 17 April 2017

Resmi, siti. 2005. Perpajakan Teori dan Kasus Buku 1 Edisi Kedua. Jakarta. Penerbit Salemba Empat.

Sosrodjojo, Indra. 2011. Cara Mudah Menghitung PPh Pasal 21 . Jakarta, PT. Elex Media Komputindo.

Undang-undang PPh Pasal 21 tahun 2016. Tersedia pada http://www.pajak.go.id. Diakses tanggal 17 April 2017 